\title{
The Importance of Spatiotemporal Heterogeneity for Biodiversity in Forest-Heathland Mosaics and Implications for Heathland Conservation
}

\author{
Samira Mobaied ${ }^{1 *}$, Jean-Jacques Geoffroy ${ }^{2}$, Nathalie Machon ${ }^{1}$ \\ ${ }^{1}$ Centre d'Ecologie et des Sciences de la Conservation (CESCO, UMR7204), Sorbonne University, MNHN, CNRS, UPMC, CP51, Paris, \\ France \\ ${ }^{2}$ Museum National d'Histoire Naturelle, CNRS UMR MNHN UPMC 7204, Conservation of Species, Restoration and Monitoring of \\ Populations, Brunoy, France \\ Email: ^mobaied@mnhn.fr, geoffroy@mnhn.fr,machon@mnhn.fr
}

How to cite this paper: Mobaied, S., Geoffroy, J.-J. and Machon, N. (2016) The Importance of Spatiotemporal Heterogeneity for Biodiversity in Forest-Heathland Mosaics and Implications for Heathland Conservation. Journal of Environmental Protection, 7, 1317-1332.

http://dx.doi.org/10.4236/jep.2016.710115

Received: June 20, 2016

Accepted: September 23, 2016

Published: September 26, 2016

Copyright $\odot 2016$ by authors and Scientific Research Publishing Inc. This work is licensed under the Creative Commons Attribution International License (CC BY 4.0).

http://creativecommons.org/licenses/by/4.0/

(c) (i) Open Access

\section{Abstract}

In biodiversity management, spatio-temporal heterogeneity is important to consider conserving high levels of habitat diversity and ecosystems. In this study, we investigated the relationship between landscape spatio-temporal heterogeneity and biodiversity in a mosaic-landscape, located in the Fontainebleau forest (France). The diversity of successional stages along a gradient from heathland to forest as well as the persistence of Calluna vulgaris (L.) Hull in different forest stands was examined in order to find how the numerous patches of European Heathland habitat embedded in this area should be maintained. The results indicated that in the areas of high spatio-temporal heterogeneity, a general increase is observed in species richness, in particular for vascular plants, bryophytes and carabids. C. vulgaris persisted in coniferous stands and young mixed stand but decreased under deciduous trees and old mixed stands. The Ellenberg's values for light, nutrients and acidity, show the persistence of favorable enviromental conditions for heathland vegetation under coniferous stands and young mixed stands. These results enable us to offer recommendations to better manage mosaic-landscape biodiversity, and in particular, the heathland semi-natural habitats in the Fontainebleau forest and elsewhere in Europe.

\section{Keywords}

Spatiotemporal Heterogeneity, Conservation Management, Calluna vulgaris, Biodiversity 


\section{Introduction}

Mosaic-landscape structures consist of an alternation of habitat patches such as open habitats and closed vegetation areas. Such landscapes host and maintain high levels of biodiversity [1]. Since habitats differ in their abiotic and biotic characteristics, their heterogeneity comprises a large set of conditions conducive to presence of large number of species [2]. However, each habitat type has to cover a sufficient surface to efficiently allow coexistence of numerous species. Furthermore, such landscapes are subjected to natural successional dynamics. These mosaics tend to disappear in favor of a more uniform closed habitat. Thus, maintaining them represents a major challenge for management and conservation of biodiversity. Many species associated with the open part of those heterogeneous habitats are threatened to extinction, as the result of habitat homogenization.

European heathlands are open habitats characterized by dwarf shrubs of Ericaceae. They have been shaped and maintained for centuries by human's activities. Changes in agricultural practices and economic priorities led to the decrease of heathlands in favour of forest formations [3]. Since the designation of the heathlands in Annex I of the EC Habitats Directive [4] as natural habitat type of community interest, management practices aim increasingly to preserve heathlands species and habitats [5]. Repeated interventions are required to thwart processes of natural succession. Under prevailing circumstances of environmental changes (climate and nitrogen deposition), conservation of heathland becomes more difficult, and requires more effort. The increase of nitrogen deposition rates in terrestrial ecosystems, improving soil fertility, causes the disappearance of heathlands that are restricted to acid, nutrient-poor soils and favours the settlement of forest or grass species [6] [7]. Thus, maintaining heathlands requires more intensive management practices [8] and increases their cost [9].

Calluna vulgaris (L.) Hull is the dominant plant species of dry heathlands. Several studies [10] [11] have previously shown that drought and elevated nitrogen $(\mathrm{N})$ deposition led to faster ageing and mortality of $C$. vulgaris, thus favouring succession from heathland to other vegetation communities. In addition, other factors such as fragmentation, isolation and particular adjacent land uses also affect conservation of heathland species [12] [13].

The most economical management methods such as regular mechanical cuttings and woody species removal are inadequate by themselves to maintain specific species in heathland fragment in the middle of a forest matrix. These conditions require additional methods to better control grass species [14].

In the Fontainebleau forest (50 km south from Paris, France), heathland is still present as small patches embedded in more woody areas forming very interesting mosaic-landscapes hosting particular species. The aim of this study is to improve the knowledge on this rare habitat in order to inform the best management decisions.

In this forest, the presence of acid sandy soils and the traditional agro-pastoralism had favored the establishment and maintenance of the heathlands over thousands of years. The abandonment of the ancestral land uses since the second half of the 20th 
century has caused the decrease of heathlands. In a previous study we had observed vegetation changes between 1946 and 2003 in this region [15]. The results showed that $60 \%$ of heathland had been colonised by tree species during this period, forming the present mosaic-landscapes. Nowadays, 1400 ha of heathland remain, in fragmented patches embedded in an oak-pine forest that is integrated within a Managed Biological Reserves (RBD). Fontainebleau contains 5\% of the total area covered by European dry heathland semi-natural habitat in the French mainland (heathland habitat code 4030, annex I of the Habitats Directive) Natura 2000 [16]. Since the early nineties, the National Forest Office (ONF) attempt to preserve many patches of heathland, in cutting regularly new plantlets of woody species.

In this present study, we examined the species richness in vascular plants, bryophytes and carabid beetles and the vegetative cover of $C$. vulgaris in the interfaces of heathland/ forest areas. The objectives were to 1 ) investigate the relationship between landscape spatio-temporal heterogeneity and biodiversity in this mosaic-landscape, 2) investigate the persistence of $C$. vulgaris and analyse the Ellenberg's scores for light, nutrients and acidity in different forest stands; and finally 3 ) assess these data within the context of heathland conservation, to give general recommendations on the most appropriate management methods for the long term conservation of mosaic-landscape biodiversity, and particularly for this semi-natural heathland habitat in these specific spatial conditions.

\section{Materials and Methods}

\subsection{The Study Site}

The state-owned forest of "Les Trois Pignons" ( $\left.3307 \mathrm{ha}, 48^{\circ} 2^{\prime} \mathrm{N}, 2^{\circ} 3^{\prime} \mathrm{E}\right)$ is a part of the Fontainebleau forest massif and consists in a mosaic of forest and open habitats, including 83 ha of pure managed heathland, 540 ha of heathland partly colonised by trees and embedded in a deciduous and conifer forest matrix. This study was carried out on three sites of heathlands more or less colonised by forest species, i.e. at different phases of the heathland-forest dynamic. Each site covered a surface of $1 \mathrm{~km}^{2}$ : They are called "Mares aux Joncs" (abbreviated to "Ma") "Chanfroy" (Ch) and the "Cul du Chien" ( $\mathrm{Cl}$ ) (Figure 1).

\subsection{The Landscape Spatio-Temporal Heterogeneity}

The dynamics of the interfaces heathland-forest in this area since the 1940s was obtained from maps of the study sites at different periods. Thus, we were able to distinguish between 5 classes which represent the date of the first appearing forest and thus the age of forest in each patch in years $(0 \mathrm{y}, 20 \mathrm{y}, 40 \mathrm{y}, 60 \mathrm{y},>80 \mathrm{y})$. These classes are indicated in Table 1(a).

The interpretation of aerial photos (BD ORTHO IGN 2003) permitted to map the vegetation cover, and to distinguish between 8 vegetation cover classes ( $\mathrm{S}$, L, Heath, WL, CF, DF, FM, W), which are described in detail in Table 1(b).

In order to obtain the map of spatial and temporal heterogeneity of the study sites, 
Table 1. Descriptions of different categories used in the classification of study sites. (a) List of different age classes forest, established by observing the dynamics of afforestation since 1946. (b) List of different types of the physiognomic classification of vegetation determined by the interpretation of aerial photos. (c) List of different types of forest stand established by detreminig cover of dominant species using the method recommended by Braun-Blanquet (1932).

(a)

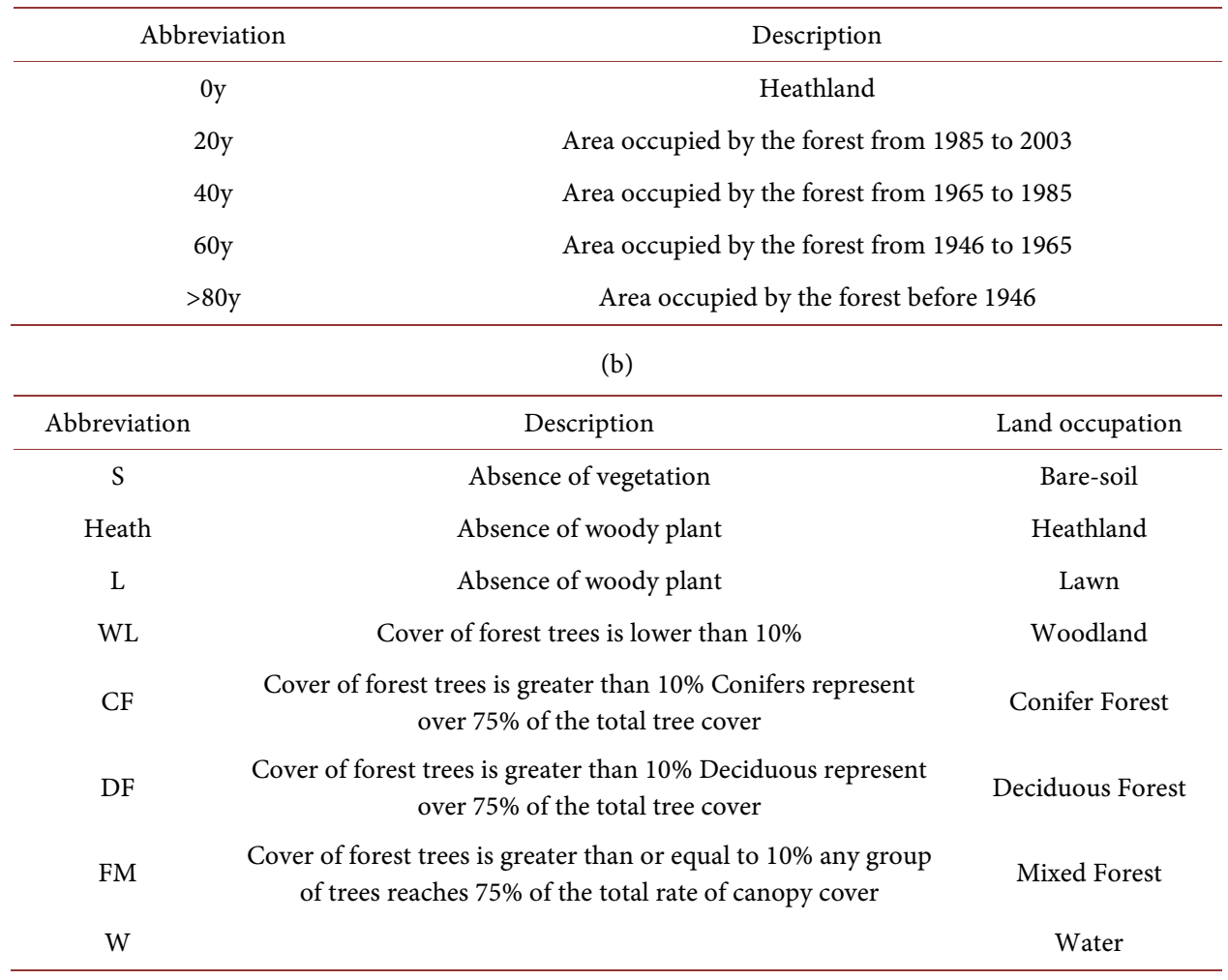

(c)

\begin{tabular}{ccc}
\hline Abbreviation & Description & Recovery rates by species \\
\hline Pis & Pinus sylvestris & Pinus sylvestris $50 \%-75 \%$ \\
PisBet & Pinus sylvestris and Betula pendula & $\begin{array}{c}\text { Pinus sylvestris } 25 \%-50 \% \\
\text { Betula pendula } 5 \%-25 \%\end{array}$ \\
QurBetPis & Quercus robur, Betula pendula and & Quercus robur $25 \%-50 \%$ \\
& Pinus sylvestris & Betula pendula $25 \%-50 \%$ \\
PisQur & Pinus sylvestris $5 \%-25 \%$ \\
& Pinus sylvestris and Quercus robur & Pinus sylvestris $75 \%$ \\
& & Quercus robur $25 \%-50 \%$ \\
QurCasPis & Quercus robur, Castanea sativa, & Quercus robur $25 \%-50 \%$ \\
& Pinus sylvestris and/or Pinus pinaster & Pinus sylvestris $5 \%-25 \%$ \\
& & Pinus pinaster $5 \%-25 \%$
\end{tabular}

we combined the two previous maps (Figure 2). We covered the three study sites with typical square window-grid of $200 \times 200 \mathrm{~m}$, i.e. 75 plots. Heterogeneity was defined as the number of vegetation patches recorded by window. Subsequently, three categories 


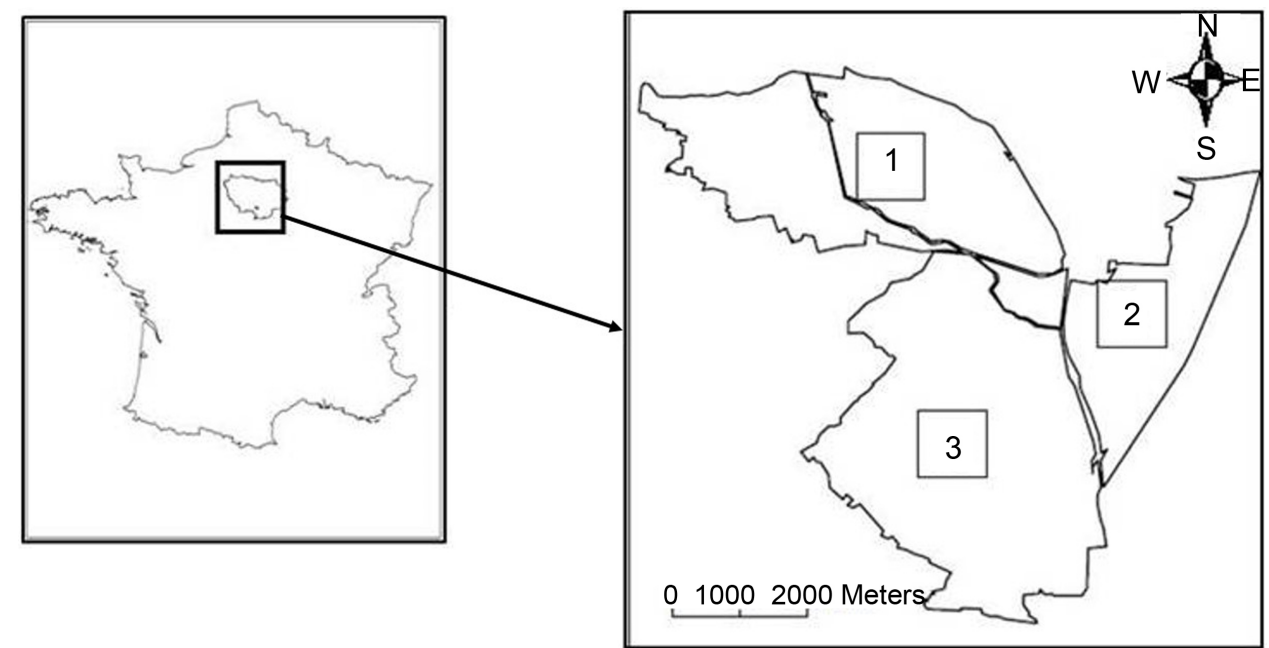

Figure 1. Location of the three study sites in the (Trois Pignons) forest 1, Mares aux Joncs (Ma) 2, Chanfroy $(\mathrm{Ch})$ and 3, Cul du Chien $(\mathrm{Cl})$. Located at the coordinates $48^{\circ} 2^{\prime} \mathrm{N}, 2^{\circ} 3^{\prime} \mathrm{E}$.

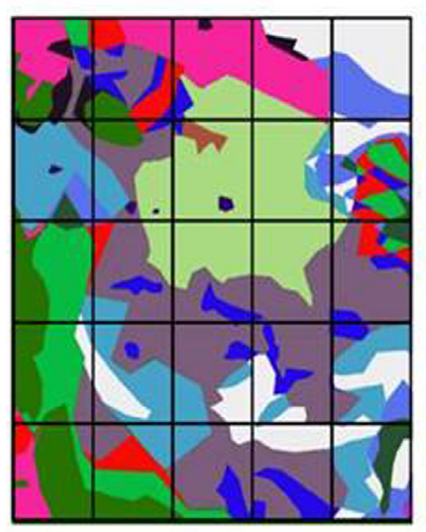

MA

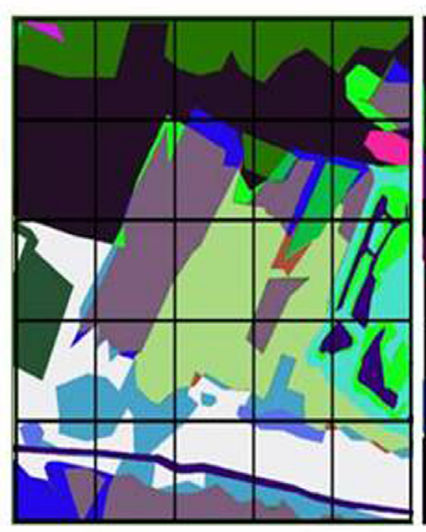

$\mathrm{CH}$
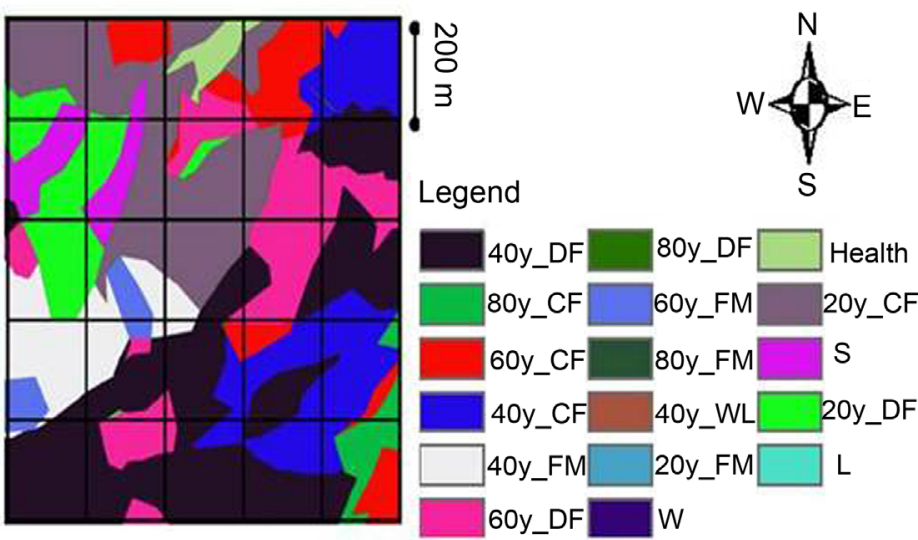

$\mathrm{CU}$

Figure 2. The map of spatial and temporal heterogeneity in the modern forested landscapes.

of heterogeneity were distinguished, 1) Habitat and temporal heterogeneity (Het-HabTemp) refers to areas with more than two patches of forest stands of different ages, and more than two patches of different habitats represented in a single window, 2) Temporal heterogeneity (Het-Temp), when there are more than two forest patches of different ages represented in a window, and 3) Homogeneous area (Homog), for less than (or equal to) two patches of different classes represented in a window.

\subsection{Biodiversity Inventory}

Biodiversity was studied at the center of the 75 plots previously defined. Three taxonomic groups were observed: 1) Vascular plants are recognised as essential groups for biodiversity studies [17]; 2) Bryophytes, a group known to be particularly sensitive to environmental changes [18] [19] and finally 3) carabids, which indicates recent developments and short-term functional changes [20]. Local diversity is quantified through 
the species richness (SR) (the total number of species per unit area) and the Shannon index $(\mathrm{H})$, (measure of species abundance and richness [21] [22]) within the three taxonomic groups, in each cell of the grid.

\subsection{Vegetation Survey}

At each of the 75 sampling points, vegetation (vascular plants and bryophytes) was recorded using the Braun-Blanquet method [23]. To determine the plot sizesused for phytosociological sampling of European vegetation phytosociological surveys we used the method set out in Milan and Zdenka [24], were carried out on areas adjusted according to the type of vegetation cover $\left(16 \mathrm{~m}^{2}\right.$ for the heathland, $64 \mathrm{~m}^{2}$ for woodland and 200 $\mathrm{m}^{2}$ in the forest).

Following Schaffersand Sýkora [25] and knowing the Ellenberg indexes of each species recorded at each of the 75 points, we calculate for each point the mean Ellenberg indicator values for acidity (ER), nitrogen (EN) and light (EL) [26] of the herbaceous vegetation.

\subsection{Carabid Sampling}

The beetles were sampled at the 75 sampling points using pitfall traps i.e. plastic cups containing monopropylene glycol with a water and detergent solution. Two pitfall traps were placed at each point $10 \mathrm{~m}$ from each other from 15th May 2009 until 29th May 2009, and again from 29th May 2009 until 12th June 2009. All carabid beetles fallen in the pitfall traps were identified at the species level using Jeannel [27] as a reference.

\subsection{Data Analyses}

\subsubsection{Biodiversity Investigation}

Diversity index data were integrated into a point-vector map within the GIS software package.

A geostatistical study was conducted in order to obtain the maps of both of global species richness index and Shannon's diversity index based on observational points. To do this, we interpolated values at unobserved points using a kriging procedure using the Geostatistical Analyst module of the Arc GIS 9.2 ESRI ${ }^{\circledast}$ software [28] [29]. This method uses variogram to express the spatial variation. It minimizes the error of predicted values which are estimated by spatial distribution of the predicted values [30] [31].

At each of the 75 points, the means of the diversity indices were calculated and the spatiotemporal heterogeneity classes were determined, and subsequently, the resulting attribute table was imported into the standard Excel ${ }^{\oplus}$ software (2007) where we conducted a multivariate analysis using XLSTAT ${ }^{\oplus}$ software [32].

A nonparametric statistical procedure, (Kruskal-Wallis analysis of variance) was used to compare species richness and Shannon diversity, across the three spatiotemporal categories. A posteriori comparisons of means were performed by a Bonferroni nonparametric procedure $(\mathrm{P}<0.05)[33]$. ( $\mathrm{P}$-value is the probability of observing a test static 
value as or more extreme than the test statistic created from one's data if the null hypothesis is true.)

Plots dominated by lawns or old woods $(>80$ y) have been excluded from analysis because this type of vegetation can not be considered as part of natural dynamics of reforestation. It is rather the result of human activities.

\subsubsection{Calluna vulgaris Investigation}

We used the Braun-Blanquet cover-abundance scale to assess the presence of $C$. vulgaris. We compared the persistence of $C$. vulgaris and the analyses on Ellenberg values amongst the different stages of afforestation for two levels: 1$)$ the age of afforestation (0 $y, 20 y, 40 y, 60 y,>80 y$ ) and 2) the type of forest stands (Pis, PisBet, PisBetQur, PisQur, QurCasPis), which was obtained from our previous field survey Table 1(c) [15]. We used a one-way Analysis of variance procedure (ANOVA). Pair mean comparisons were performed by using Fisher's Least-Square-Difference (LSD) test with a 95\% confidence interval.

\section{Results}

\subsection{Biodiversity and Landscape Spatio-Temporal Heterogeneity}

In the surveyed plots, a total of 76 vascular plant species were identified, 40 of them covered more than 10 percent of the plots. Seventeen bryophyte species were observed and a total of 636 individuals belonging to seven different carabid species were collected.

The maps of global species richness index (Figure 3 ) showed that the total species richness increases from homogeneous habitat to heterogeneous habitat. The maps of the Shannon index (Figure 4) showed that a correlation existed between habitat heterogeneity and the diversity of each of taxonomic group species.

The Shannon index of vascular plant varied between 0.9 and 1.9, while the Shannon index of Bryophyte varied from 0.5 to 1.5 . Finally, for the carabid beetles, the Shannon index varied between 0.16 and 0.83 .

A statistically significant species richness increase was noted in spatiotemporal heterogeneous area (Het-Hab-Temp), when compared to temporal heterogeneous area

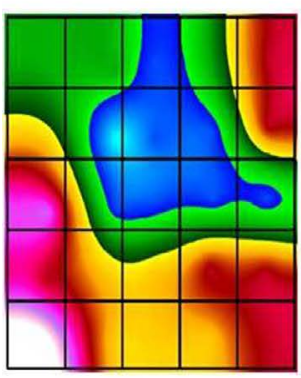

RSMA

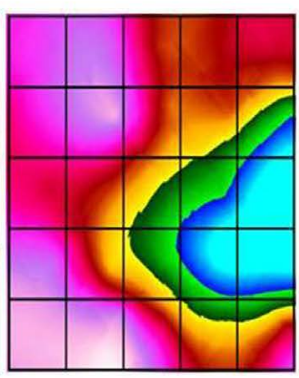

$\mathrm{RSCH}$

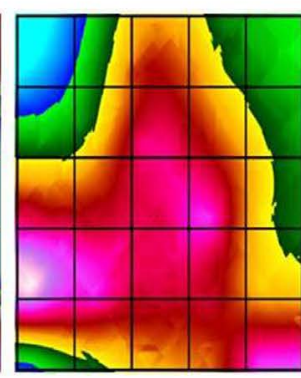

RSCU

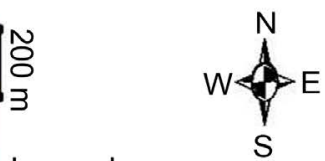

Legend

High: 15.2242

Low: 8.00554

Figure 3. Predictive maps of global species richness index (SR) in Mares aux Joncs (Ma), Chanfroy $(\mathrm{Ch})$ and $\mathrm{Cul}$ du $\mathrm{Chien}(\mathrm{Cl})$. 


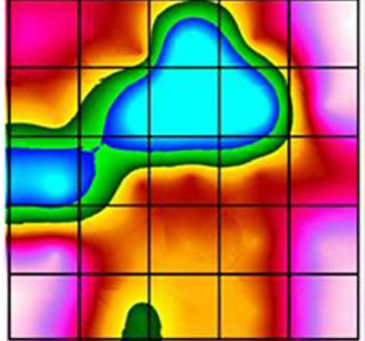

SHPVMA

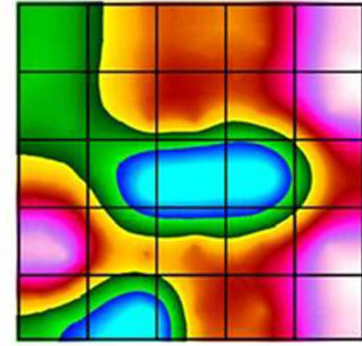

SHBRMA

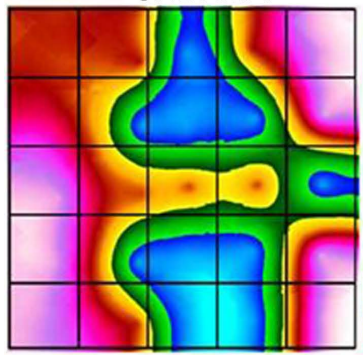

SHCAMA

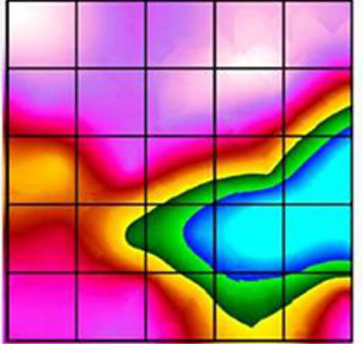

SHPVCH

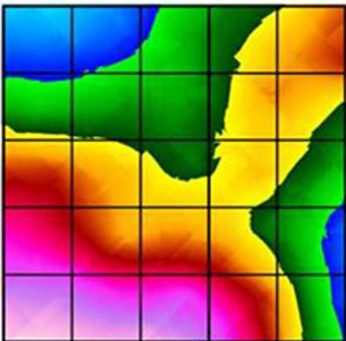

$\mathrm{SHBRCH}$

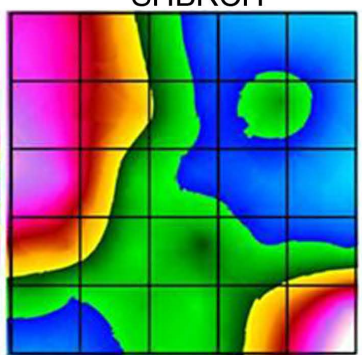

$\mathrm{SHCACH}$

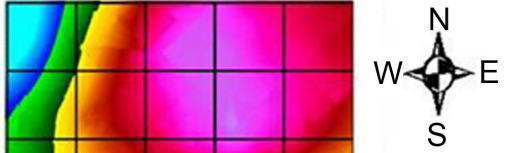

S

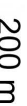

SHPVCU

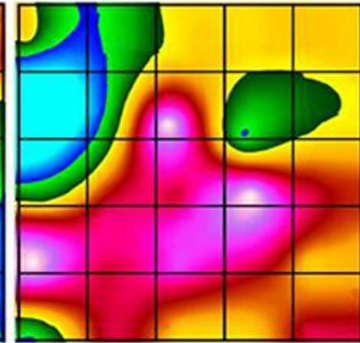

SHBRCU

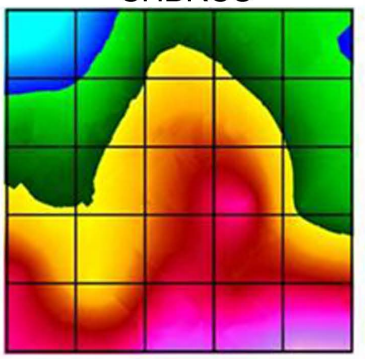

SHCACU

Legend

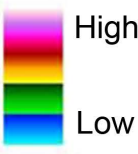

Figure 4. Predictive maps of Shannon index (SH) for vascular plant (PV), Bryophyte (BR) and carabid beetles (CR), in Mares aux Joncs (Ma), Chanfroy (Ch) and Cul du Chien $(\mathrm{Cl})$.

(Het-Temp) and homogeneous area (Homog) (Figure 5(a)).

The Shannon index was significantly greater $(\mathrm{P}<0.05)$ in the in spatio temporal heterogeneous area (Het-Hab-Temp) compared to homogeneous area (Homog) for the three taxonomic groups, but no other significant differences were observed between the Shannon index values in temporal heterogeneous area (Het-Temp) and the other categories (Figures 5(b)-(d)).

\subsection{The Persistence of $C$. vulgaris in Different Forest Stands}

When we examined the cover-abundance values of $C$. vulgaris as a function of the age of the forest stands, we observed that $C$. vulgaris persisted throughout woodland establishment for around 60 year after abandonment, but decreased significantly in the area that was forested from more than 80 year (Figure 6(a)).

The cover-abundance values of $C$. vulgaris as a function of the type of forest stands showed that $C$. vulgaris persisted in coniferous stands (Pis) and in young mixed stand (Pis Bet) and decreased continuously throughout forest colonization and maturation. When compared to open heathland $C$. vulgaris showed a significant decrease in (QurCasPis) (Figure 6(b)). We noted also that $C$. vulgaris cover-abundance in coniferous 

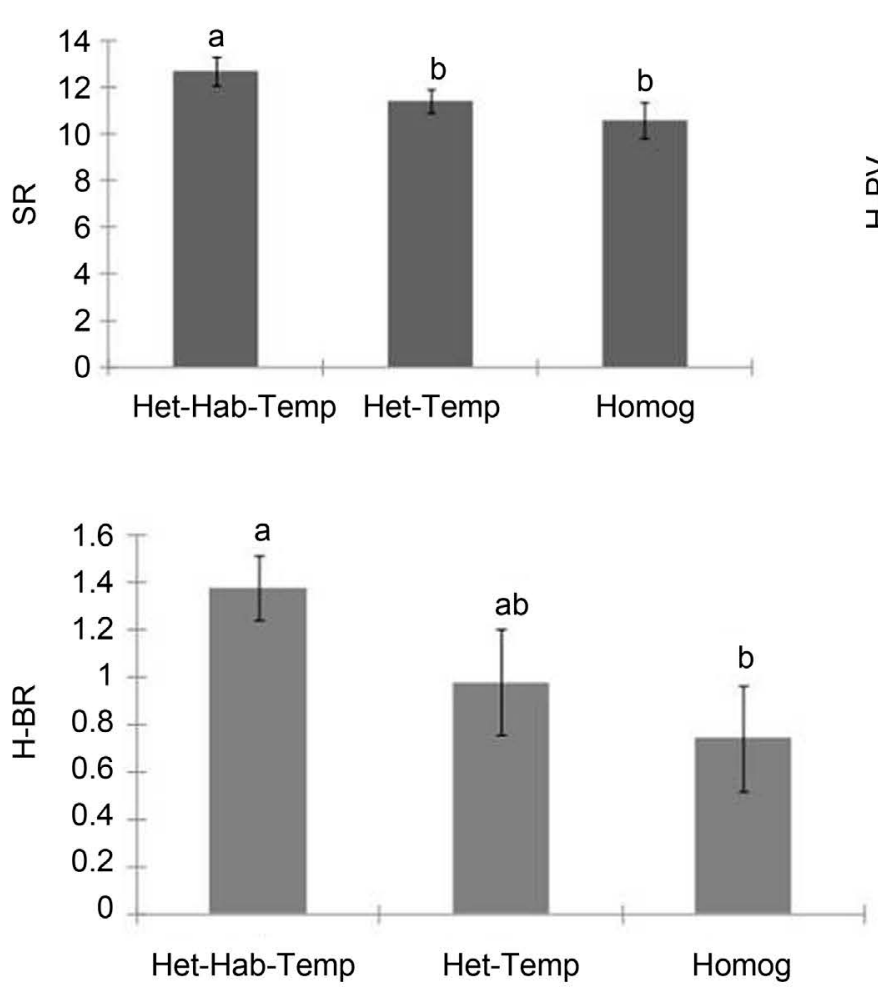
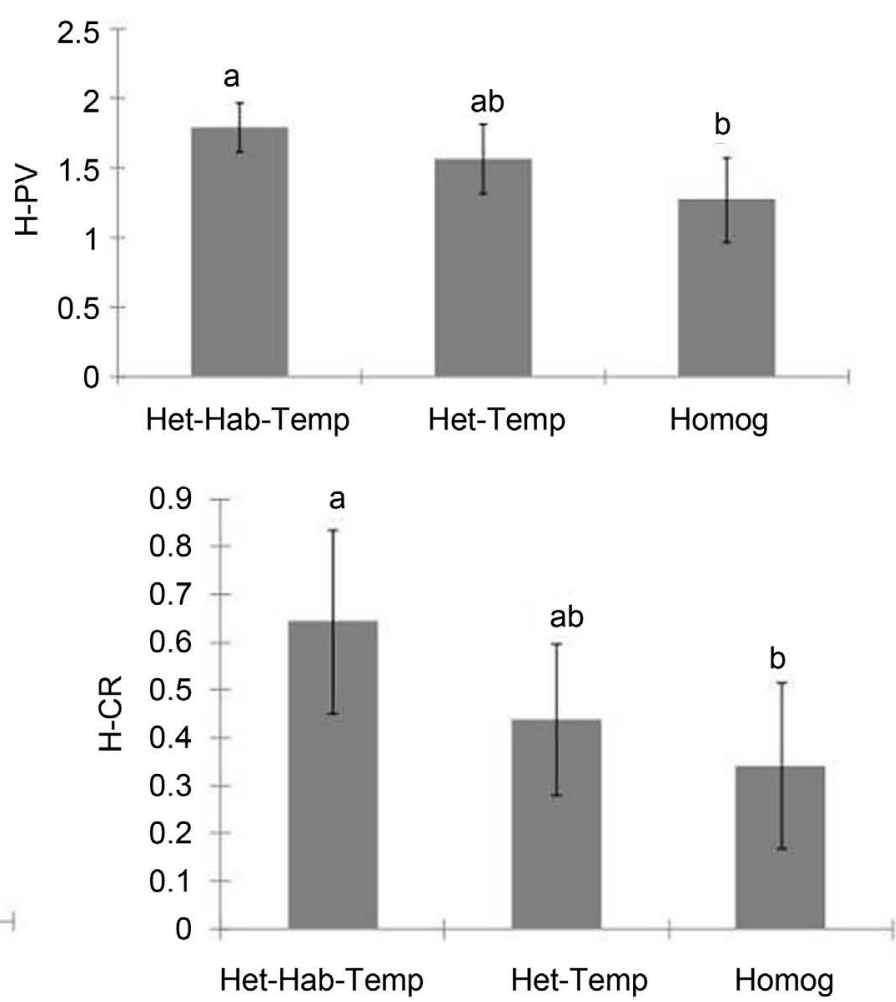

Figure 5. Comparison between species richness (SR) and Shannon index (H) values for vascular plant (PV), Bryophyte (BR) and carabid beetles (CR) among three categories of heterogeneity: A same italic letter indicates non-significant differences (Bonferroni nonparametric procedure $\mathrm{P}<0.05)$.
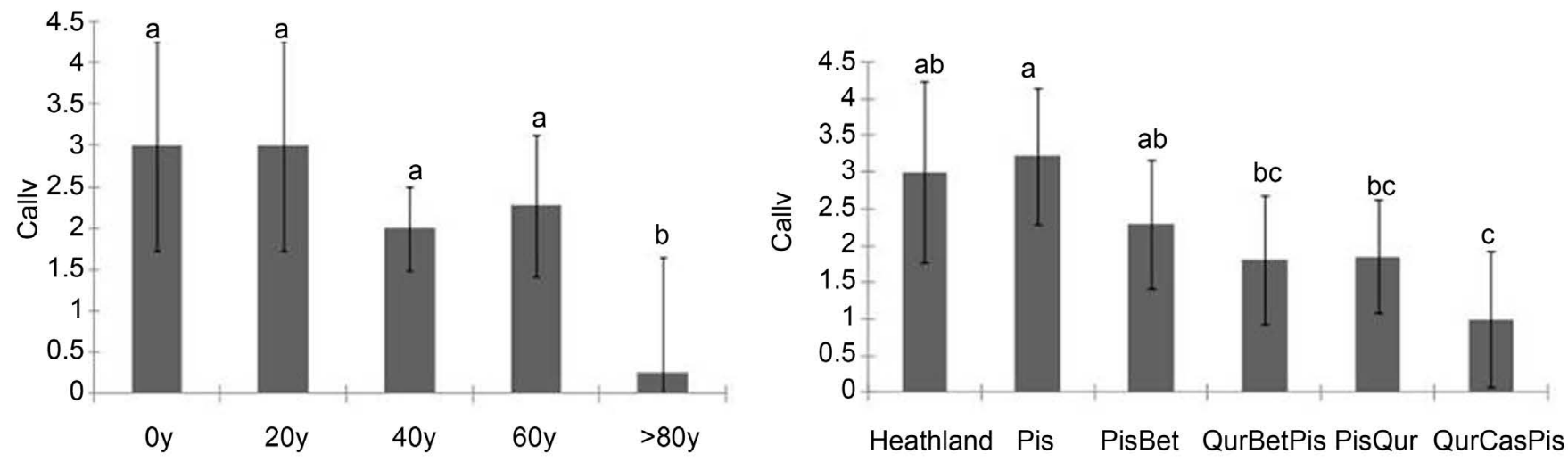

Figure 6. Comparison of cover-abundance values of $C$. vulgaris as a function of the age of the forest stands and as a function of the type of forest stands: A same italic letter indicates non-significant differences (LSD procedure $\mathrm{P}<0.05$ ).

stands (Pis) was higher than in managed heathland.

The Ellenberg score for nitrogen (EN) increased continuously throughout forest maturation. We noted that there was no significant difference between Heathland and earlier afforestation stages (PisPisBet), while the Ellenberg score for nitrogen was significantly higher in mature forest stands (PisBetQur, PisQur, QurCasPis) (Figure 7).

The Ellenberg scores for acidity (ER) showed also a significant difference between the earlier stages (heathlands, pure pine stands and pine birch stands) and the later stages 

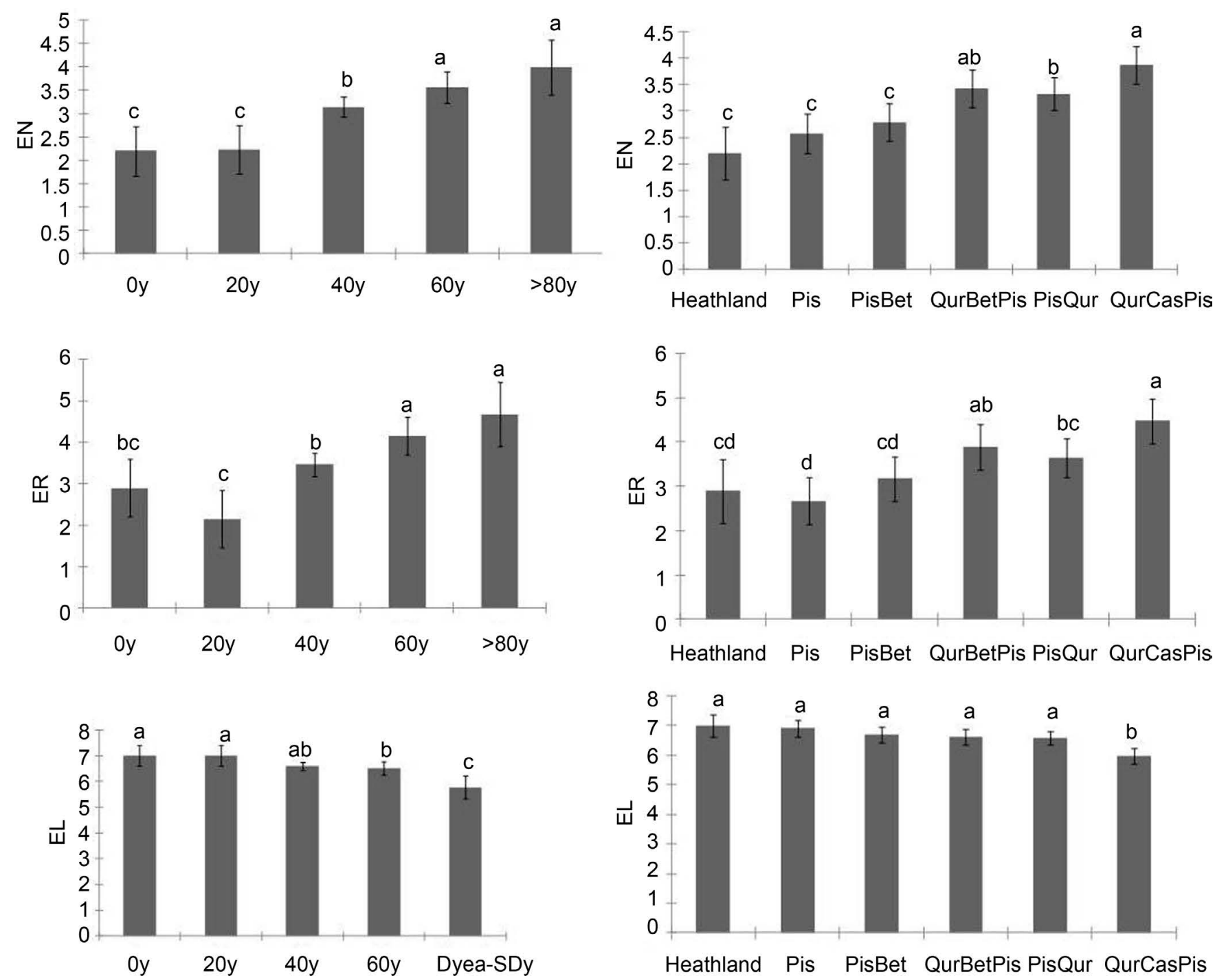

Figure 7. Comparison of Ellenberg score for nitrogen (EN), for acidity (ER) and for light (EL) as a function of the age of the forest stands and as a function of the type of stands: A same italic letter indicates non-significant differences (LSD procedure $\mathrm{P}<0.05$ ).

(old mixed stands) (Figure 6).

The Ellenberg scores for light (EL) decreased continuously throughout the stages of forest colonization and maturation. This decrease was significantly different in forest stands older than 80 year and corresponding mostly to QurCasPis (Figure 7).

\section{Discussion}

The different patch types observed displayed different habitats and species compositions. It is well known that landscape heterogeneity systems are usually advantageous for species richness and diversity [1] [34]-[38]. Several studies showed that the degree of landscape heterogeneity had a positive effect on plant and the beetle diversities [39] [40], but also for other taxa that are outside the scope of the present study [41].

Several studies used landscape heterogeneity as general predictor for biodiversity 
quality by establishing the relationships between landscape diversity and plant and invertebrate diversity [42]-[44].

Landscape heterogeneity is the result of the actions and interactions of the formative processes operating on a landscape at a point in time [45].

In the cases presented in this study, it is the afforestation that causes fundamental changes in ecosystem structure and functioning. Afforestation causes changes in shading, micro-climate, nutrient availability, available moisture and soil types. Forest expansion alters species richness in modifying degree of landscapes heterogeneity. Consequently, if no intervention is carried out to prevent forest expansion, the landscape suffers a loss of heterogeneity [46]. Therefore in order to maintain both high environmental diversity and heathlands habitats, an efficient management should be performed to maintain the different stages of dynamics of the ecological systems represented by this mosaic landscapes.

The result on the persistence of $C$. vulgaris along earlier afforestation stages is in agreement with the other studies, i.e. heathland species persist even in the early stages of forest colonization [47]-[49]. This persistence seems to be linked to soil fertility and acidity as given by Ellenberg values of plant communities for nutrients and acidity. We note that the values between heathland and both Pinus sylvestris woodland and Pinus sylvestris and Betula pendula woodland are similar, but that an increase of these two values is obvious with the presence of Quercus robur. This is likewise correlated to the decrease of $C$. vulgaris cover.

Pinus sylvestris needle litter is nutrient-poor [50] [51], and acidify the soil [52] [53] thereby maintaining the favorable soil properties for $C$. vulgaris. In contrast, $Q$. robur significantly changes soil fertility and acidity [54]. Nevertheless, we remark that $C$. vulgaris vegetation cover is lower in areas colonized by $P$. sylvestris and B. pendula, relatively to $P$. sylvestris woodland.

The presence of birch increase soil $\mathrm{pH}$ [55] and nutrient availability [56] and thus changed both soil fertility and acidity. In managed heathland, pines do not survive when cut at the ground level, while $B$. pendula produce several new shoots. Old $B$. pendula shoots favor grass expansion to the detriment of heathland species [15]. This may explain the convergence between managed heathland and areas colonized by both P. sylvestris and B. pendula.

\section{Conclusion and the Implication for Heathland Management Conservation}

Conservation management has to take the spatial conditions into account, but also the temporal development of different environmental characteristics that affect the habitat. In our study sites, the forest had colonised $60 \%$ of heathland since the 1940's [15] through the natural phenomenon of vegetation succession.

The remaining heathland patches are embedded in the centre of a dynamic periurban forest, subject to elevated nitrogen deposition.

The simple management methods that have been used until today have become 


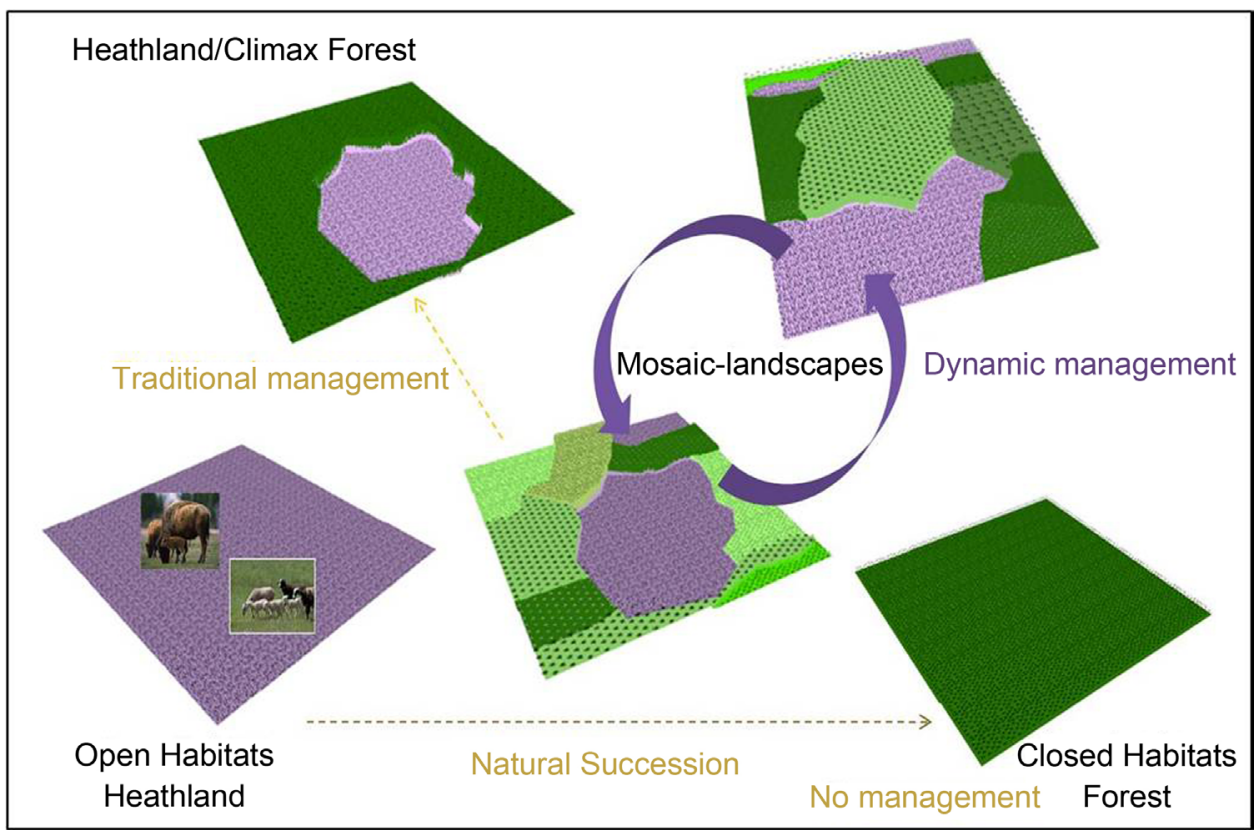

Figure 8. Scheme illustrating the impacts of different management methods on landscape heterogeneity.

inefficient under these conditions [14]. A revision of the management methods is now required deal with the new spatial conditions. New techniques are also necessary to maintain mosaics of woodland and heathland habitats, with the aim to support structural complexity that creates a great variety of niches in this region (Figure 8).

To achieve this objective, we suggest a rotational shift between heathland and woodland, which should include: 1) maintaining a fixed ratio for each of the heathland and wooded areas of varying degrees of canopy closure; 2) managing zones according to the following categories: a) heathland, b) areas wooded for 20 years, c) areas wooded for 40 years; 3 ) interventions should be scheduled every 20 years, which should include: a) clear-cutting areas wooded for 40 years and b) use controlled burning [57] [58] for restoring heathland in this area.

The implementation of these proposals will allow the maintenance of: 1) mosaic landscapes of heathland and varying wooded areas, and the dynamic vegetation succession among them; 2) larger areas of heathland, and thereby maintain of habitat quality. Finally, 3) the costs of these measures can be reduced by valorization of the 40 years old wood cut during the operation. In that manner, conservation management could certainly become both ecologically interesting and economically self-funded.

\section{Acknowledgements}

We thank Jacques BARDAT, (Bryophytes specialist, Museum National d'Histoire Naturelle) for his valuable help in the bryophytes study.

\section{References}

[1] Burel, F. and Baudry, J. (2001) Ecologie du paysage. Tec and Doc-Lavoisier, Paris. 
[2] Tilman, D. and Kareiva, P. (Eds.) (1997) Spatial Ecology: The Role of Space in Population Dynamics and Interspecific Interactions. Princeton University Press, Princeton.

[3] Webb, N.R. (1998) The Traditional Management of European Heathlands. Journal of Applied Ecology, 35, 987-990. http://dx.doi.org/10.1111/j.1365-2664.1998.tb00020.x

[4] EC Habitats Directive (1992) Council Directive 92/43/EEC of 21 May 1992 on the Conservation of Natural Habitats and of Wild Fauna and Flora. Brussels, Belgium.

[5] Price, E.A.C. (2003) Lowland Grassland and Heathland Habitats. Routledge, London. http://dx.doi.org/10.4324/9780203446652

[6] Aerts, R. and Berendse, F. (1988) The Effect of Increased Nutrient Availability on Vegetation Dynamics in Wet Heathlands. Vegetatio, 76, 63-69.

[7] Aerts, R., Berendse, F., De Caluwe, H. and Schmitz, M. (1990) Competition in Heathland along an Experimental Gradient of Nutrient Availability. Oikos, 57, 310-318.

http://dx.doi.org/10.2307/3565959

[8] Barker, C.G., Power, S.A., Bell, J.N.B. and Orme, C.D.L. (2004) Effects of Habitat Management on Heathland Response to Atmospheric Nitrogen Deposition. Biological Conservation, 120, 41-52. http://dx.doi.org/10.1016/j.biocon.2004.01.024

[9] Wamelink, G.W.W., de Jong, J.J., Van Dobben, H.F. and Van Wijk, M.N. (2005) Additional Costs of Nature Management Caused by Deposition. Ecological Economics, 52, 437-451. http://dx.doi.org/10.1016/j.ecolecon.2004.08.004

[10] Rosén, E. (1995) Periodic Droughts and Long-Term Dynamics of Alvar Grassland Vegetation on Öland, Sweden. Folia Geobotanica and Phytotaxonomica, Praha, 30, 131-140. http://dx.doi.org/10.1007/BF02812093

[11] Lageard, J.G.A., Wilson, D.B., Cresswell, N., Cawley, L.E., Jones, H.E. and Caporn, S.J.M. (2005) Wood Growth Response of Calluna vulgaris (L.) Hull to Elevated N Deposition and Drought. Dendrochronologia, 23, 75-81. http://dx.doi.org/10.1016/j.dendro.2005.08.001

[12] Piessens, K., Honnay, O., Devlaeminck, R. and Hermy, M. (2006) Biotic and Abiotic Edge Effects in Highly Fragmented Heathlands Adjacent to Cropland and Forest. Agriculture, Ecosystems and Environment, 114, 335-342. http://dx.doi.org/10.1016/j.agee.2005.11.016

[13] Piessens, K., Honnay, O. and Hermy, M. (2005) The Role of Fragment Area and Isolation in the Conservation of Heathland Species. Biological Conservation, 122, 61-69. http://dx.doi.org/10.1016/j.biocon.2004.05.023

[14] Mobaied, S., Riera, B., Lalanne, A., Baguette, M. and Machon, N. (2011) The Use of Diachronic Spatial Approaches and Predictive Modelling to Study the Vegetation Dynamics of a Managed Heathland. Biodiversity and Conservation, 20, 73-88. http://dx.doi.org/10.1007/s10531-010-9947-1

[15] Mobaied, S. (2011) La dynamique spatiotemporelle de la végétation et l'organisation de la biodiversité des interfaces lande-forêt tempérée. Implication pour la gestion conservatoire des réserves naturelles. Thèse de Doctorat, soutenue le 04 Avril, Muséum National d'Histoire Naturelle, Paris.

[16] Natura 2000 Networking Programme (1992) Natura 2000 FRANCE. http://natura2000.environnement.gouv.fr/

[17] Santi, E., Maccherini, S., Rocchini, D., Bonini, I., Brunialti, G., Favilli, L., Perini, C., Pezzo, F., Piazzini, S., Rota, E., Salerni, E. and Chiarucci, A. (2010) Simple to Sample: Vascular Plants as Surrogate Group in a Nature Reserve. Journal for Nature Conservation, 18, 2-11. http://dx.doi.org/10.1016/j.jnc.2009.02.003

[18] Vanderpoorten, A. and Engels, P. (2002) The Effects of Environmental Variation on Bryophytes at a Regional Scale. Ecography, 25, 513-522. 
http://dx.doi.org/10.1034/j.1600-0587.2002.250501.x

[19] Pharo, E.J. and Zartman, C.E. (2007) Bryophytes in a Changing Landscape: The Hierarchical Effects of Habitat Fragmentation on Ecological and Evolutionary Processes. Biological Conservation, 135, 315-325. http://dx.doi.org/10.1016/j.biocon.2006.10.016

[20] Niemela, J., Haila, Y. and Punttila, P. (1996) The Importance of Small-Scale Heterogeneity in Boreal Forests: Variation in Diversity of Forest-Floor Invertebrates across the Succession Gradient. Ecography, 19, 352-368. http://dx.doi.org/10.1111/j.1600-0587.1996.tb01264.x

[21] Shannon, C.E. and Weaver, W. (1962) The Mathematical Theory of Communication. University of Illinois Press, Urbana.

[22] Hutchison, K. (1970) A Test for Comparing Diversities Based on the Shannon Formula. Journal of Theoretical Biology, 29, 151-154. http://dx.doi.org/10.1016/0022-5193(70)90124-4

[23] Braun-Blanquet, J. (1932) Plant Sociology. McGraw-Hill Book Company, New York.

[24] Milan, C. and Zdenka, O. (2003) Plot Sizes Used for Phytosociological Sampling of European Vegetation. Journal of Vegetation Science, 14, 563-570. http://dx.doi.org/10.1111/j.1654-1103.2003.tb02183.x

[25] Schaffers, A.P. and Sýkora, K.V. (2000) Reliability of Ellenberg Indicator Values for Moisture, Nitrogen and Soil Reaction: A Comparison with Field Measurements. Journal of Vegetable Science, 11, 225-244. http://dx.doi.org/10.2307/3236802

[26] Ellenberg, H., Weber, H.E., Düll, R., Wirth, V., Werner, W. and Paulissen, D. (1991) Zeigerwerte von Pflanzen in Mitteleuropa. ScriptaGeobot.

[27] Jeannel, R. (1941) Coléoptères Carabiques, I. Collection Faune de France, Vol. 39, Lechevalier, Paris, 571 p.

[28] Ormsby, T., Napoleon, E., Burke, R. and Napoleon, E.J. (2004) Getting to Know ArcGIS Desktop Basics of ArcView, ArcEditor, and ArcInfo. ESRI Press, Redlands.

[29] Environmental Systems Research Institute ESRI (2006) ArcGis [Logiciel]. Version 9.2, Environmental Systems Research Institute Inc., Redlands.

[30] Krige, D. (1951) A Statical Problem to Some Basic Mine Valuation Problems on the Witwatersrand. Journal of the Chemical, Metallurgical and Mining Society of the South Africa, 52, 119-139.

[31] Isaaks, E.H. and Srivastava, R.M. (1989) An Introduction to Applied Geostatistics. Oxford University Press, New York, 413.

[32] Addinsoft (2007) XLSTAT, Analyse de données et statistique avec MS Excel. Addinsoft, New York.

[33] McDonald, J.H. (2008) Handbook of Biological Statistics. 2nd Edition, Sparky House Publishing, Baltimore.

[34] Pickett, S.T.A. and White, P.S. (1985) The Ecology of Natural Disturbance and Patch Dynamics. AcademicPress, Orlando.

[35] Turner, M.G. (Ed.) (1987) Landscape Heterogeneity and Disturbance. Ecological Studies 64, Springer Verlag, New York.

[36] Huston, M.A. (1994) Biological Diversity. Cambridge University Press, Cambridge.

[37] Forman, R.T.T. (1995) Land Mosaics. Cambridge University Press, New York.

[38] Rosenzweig, M.L. (1995) Species Diversity in Space and Time. Cambridge University Press, New York. http://dx.doi.org/10.1017/CBO9780511623387

[39] Lassau, S.A., Hochuli, D.F., Cassis, G. and Reid, C.A.M. (2005) Effects of Habitat Complex- 
ity on Forest Beetle Diversity: Do Functional Groups Respond Consistently? Diversity and Distributions, 11, 73-82. http://dx.doi.org/10.1111/j.1366-9516.2005.00124.x

[40] Ovalle, C., Del Pozo, A., Casado, M.A., Acosta, B. and De Miguel, J.M. (2006) Consequences of Landscape Heterogeneity on Grassland Diversity and Productivity in the Espinal Agroforestry System of Central Chile. Landscape Ecology, 21, 585-594. http://dx.doi.org/10.1007/s10980-005-3498-y

[41] Atauri, J.A. and de Lucio, J.V. (2001) The Role of Landscape Structure in Species Richness Distribution of Birds, Amphibians, Reptiles and Lepidopterans in Mediterranean Landscape. Landscape Ecology, 16, 147-159. http://dx.doi.org/10.1023/A:1011115921050

[42] Debinski, D.M., Kindscher, K. and Jakubauskas, M.E. (1999) A Remote Sensing and GIS-Based Model of Habitats and Biodiversity in the Greater Yellowstone Ecosystem. International Journal of Remote Sensing, 20, 3281-3291.

http://dx.doi.org/10.1080/014311699211336

[43] Luoto, M., Toivonen, T. and Heikkinen, R.K. (2002) Prediction of Total and Rare Plant Species Richness in Agricultural Landscapes from Satellite Images and Topographic Data. Landscape Ecology, 17, 195-217. http://dx.doi.org/10.1023/A:1020288509837

[44] Moser, D., Zechmeister, H.G., Plutzar, C., Sauberer, N., Wrbka, T. and Grabherr, G. (2002) Landscape Patch Shape Complexity as an Effective Measure for Plant Species Richness in Rural Landscapes. Landscape Ecology, 17, 657-669. http://dx.doi.org/10.1023/A:1021513729205

[45] Forman, R.T.T. and Godron, M. (1986) Landscape Ecology. John Wiley and Sons Ltd., New York.

[46] Marty, P., Pe'laquier, E., Jaudron, B. and Lepart, J. (2003) Spontaneous Reforestation in a Peri-Mediterranean Landscape: History of Agricultural Systems and Dynamics of Woody Species. In: Fouache, E., Ed., The Mediterranean World Environment and History, Elsevier, Paris, 183-190.

[47] Tatoni, T. and Roche, P. (1994) Comparison of Old-Fields and Forest Revegetation Dynamics in Provence. Journal of Vegetation Science, 5, 295-302. http://dx.doi.org/10.2307/3235852

[48] Debussche, M., Debussche, G. and Lepart, J. (2001) Changes in the Vegetation of Quercus pubescens Woodland after Cessation of Coppicing and Grazing. Journal of Vegetation Science, 12, 81-92. http://dx.doi.org/10.1111/j.1654-1103.2001.tb02619.x

[49] Curt, T., Prévosto, B., Klesczewski, M. and Lepart, J. (2003) Post-Grazing Scots Pine Colonization of Mid-Elevation Heathlands: Population Structure, Impact on Vegetation Composition and Diversity. Annals of Forest Science, 60, 711-724. http://dx.doi.org/10.1051/forest:2003065

[50] Johansson, M.B. (1995) The Chemical Composition of Needle and Leaf Litter from Scots Pine, Norway Spruce and White Birch in Scandinavian Forests. Forestry, 68, 49-62. http://dx.doi.org/10.1093/forestry/68.1.49

[51] Priha, O., Grayston, S.J., Hiukka, R., Pennannen, T. and Smolander, A. (2001) Microbial Community Structure and Characteristics of the Organic Matter in Soils under Pinus sylvestris, Picea abies and Betula pendula at Two Forest Sites. Biology and Fertility of Soils, 33, 17-24. http://dx.doi.org/10.1007/s003740000281

[52] Millar, C.S. (1974) Decomposition of Coniferous Leaf Litter. In: Dickinson, C.H. and Pugh, G.J.F., Eds., Biology of Plant Litter Decomposition, Vol. 1, Academic Press, London, 105128. http://dx.doi.org/10.1016/b978-0-12-215001-2.50010-6

[53] Sariyildiz, T., Anderson, J.M. and Kucuk, M. (2005) Effects of Tree Species and Topography 
on Soil Chemistry, Litter Quality, and Decomposition in Northeast Turkey. Soil Biology \& Biochemistry, 37, 1695-1706. http://dx.doi.org/10.1016/j.soilbio.2005.02.004

[54] Nornberg, P., Sloth, L. and Nielsen, K.N. (1993) Rapid Changes of sandy Soils Caused by Vegetation Changes. Canadian Journal of Soil Science, 73, 459-468. http://dx.doi.org/10.4141/cjss93-047

[55] Miles, J. (1981) Problems in Heathland and Grassland Dynamics. Vegetatio, 46, 61-74. http://dx.doi.org/10.1007/BF00118384

[56] Sanborn, P. (2001) Influence of Broadleaf Trees on Soil Chemical Properties: A Retrospective Study in the Sub-Boreal Spruce Zone, British Columbia, Canada. Plant and Soil, 236, 75-82. http://dx.doi.org/10.1023/A:1011973402414

[57] Mallik, A.U. and Gimingham, C.H. (1985) Ecological Effects of Heather Burning. II. Effects on Seed Germination and Vegetative Regeneration. Journal of Ecology, 73, 633-644. http://dx.doi.org/10.2307/2260500

[58] Valbuena, L. and Trabaud, L. (2001) Contribution of the Soil Seed Bank to Post-Fire Recovery of a Heathland. Plant Ecology, 152, 175-183.

http://dx.doi.org/10.1023/A:1011419721307

Submit or recommend next manuscript to SCIRP and we will provide best service for you:

Accepting pre-submission inquiries through Email, Facebook, LinkedIn, Twitter, etc. A wide selection of journals (inclusive of 9 subjects, more than 200 journals)

Providing 24-hour high-quality service

User-friendly online submission system

Fair and swift peer-review system

Efficient typesetting and proofreading procedure

Display of the result of downloads and visits, as well as the number of cited articles Maximum dissemination of your research work

Submit your manuscript at: http://papersubmission.scirp.org/

Or contact jep@scirp.org 